Article

\title{
Spatio-Temporal Trend Analysis of Rainfall and Temperature Extremes in the Vea Catchment, Ghana
}

\author{
Isaac Larbi ${ }^{1, *}$, Fabien C. C. Hountondji ${ }^{2}$, Thompson Annor ${ }^{3}{ }^{(}$, Wilson Agyei Agyare ${ }^{4}$, \\ John Mwangi Gathenya ${ }^{5}$ and Joshua Amuzu ${ }^{6}$ (i) \\ 1 Climate Change and Water Resources, West African Science Service Centre on Climate Change and Adapted \\ Land Use (WASCAL), Universite D'abomey Calavi, 03 BP 526 Cotonou, Benin \\ 2 Faculté d'Agronomie, University of Parakou, Parakou BP 123, Benin; fabianh@yahoo.com \\ 3 Department of Physics, Kwame Nkrumah University of Science and Technology (KNUST), Kumasi, Ghana; \\ tommykak@yahoo.com \\ 4 Department of Agricultural Engineering, Kwame Nkrumah University of Science and Technology, \\ Kumasi, Ghana; wagyar@yahoo.co.uk \\ 5 Soil, Water, and Environmental Engineering Department, Jomo Kenyatta University of Agriculture and \\ Technology (JKUAT), Nairobi 62000, Kenya; j.m.gathenya@jkuat.ac.ke \\ 6 West African Science Service Center on Climate Change and Adapted Land Use (WASCAL) Headquarters, \\ CSIR Office Complex, Airport Residential Area, P.M.B CT 504, Cantonments-Accra 0233, Ghana; \\ joshua.amuzu@yahoo.com \\ * Correspondence: larbi.i@edu.wascal.org; Tel.: +233-558-282-127
}

Received: 3 September 2018; Accepted: 30 October 2018; Published: 31 October 2018

check for updates

\begin{abstract}
This study examined the trends in annual rainfall and temperature extremes over the Vea catchment for the period 1985-2016, using quality-controlled stations and a high resolution $(5 \mathrm{~km})$ Climate Hazards Group InfraRed Precipitation with Station (CHIRPS) data. The CHIRPS gridded precipitation data's ability in reproducing the climatology of the catchment was evaluated. The extreme rainfall and temperature indices were computed using a RClimdex package by considering seventeen (17) climate change indices from the Expert Team on Climate Change Detection Monitoring Indices (ETCCDMI). Trend detection and quantification in the rainfall (frequency and intensity) and temperature extreme indices were analyzed using the non-parametric Mann-Kendall (MK) test and Sen's slope estimator. The results show a very high seasonal correlation coefficient $(\mathrm{r}=0.99)$, Nash-Sutcliff efficiency ( 0.98$)$ and percentage bias $(4.4 \%$ and $-8.1 \%)$ between the stations and the gridded data. An investigation of dry and wet years using Standardized Anomaly Index shows $45.5 \%$ frequency of drier than normal periods compared to $54.5 \%$ wetter than normal periods in the catchment with 1999 and 2003 been extremely wet years while the year 1990 and 2013 were extremely dry. The intensity and magnitude of extreme rainfall indices show a decreasing trend for more than $78 \%$ of the rainfall locations while positive trends were observed in the frequency of extreme rainfall indices (R10mm, R20mm, and CDD) with the exception of consecutive wet days (CWD) that shows a decreasing trend. A general warming trend over the catchment was observed through the increase in the annual number of warm days (TX90p), warm nights (TN90p) and warm spells (WSDI). The spatial distribution analysis shows a high frequency and intensity of extremes rainfall indices in the south of the catchment compared to the middle and northern of part of the catchment, while temperature extremes were uniformly distributed over the catchment.
\end{abstract}

Keywords: extreme rainfall; Standardized Anomaly Index; gridded precipitation data; Vea catchment; warm days; warm nights 


\section{Introduction}

Climates in different parts of the world are characterized by their variability with impacts on varied sectors. This variability has increased since the 1950s, and particularly during the latest decade [1]. This is principally due to the increased concentration of anthropogenic greenhouse gases in the atmosphere as argued by some authors [2-8]. Global surface temperature has increased by $0.71{ }^{\circ} \mathrm{C}$ over the last century with significant warming observed in many regions [3]. This increase in global mean surface temperature in recent times reveals more warming of land than the oceans with diverse consequences on the livelihood of people [3,9]. The IPCC (Intergovernmental Panel on Climate Change) report [4] attests to the fact that there is the likelihood of increases in extreme climate events due to the observed global warming over recent decades. This makes studying climate extremes at the spatial and temporal scale relevant due to the fact that its impact is very devastating and can lead to loss of life and economic damages.

Extreme climatic events such as heat waves, floods and droughts affect lives and livelihoods of people over varied regions [10]. The study by [11] argues that the number of flood events in Africa has increased from 2 times per year on average before 1990 to more than 12 times per year on average during the 2000s. Droughts and floods are generating socio-economic impacts such as hunger, habitat and infrastructures' destruction. Over $40 \%$ of the populace encountered hunger situations leading to humanitarian appeals as crops failed over one-third of production compared with 2010 [12,13]. With these and other ensuing impacts, analysis of changes in extreme climatic indices is pertinent in reducing potential social, economic and ecological consequences [14,15] as this affords people the opportunity of getting timely warnings to better cope with or adapt to these extreme climate change impact. This need has prompted studies in the analysis of past trends and the prediction of the occurrence of extreme climate events on rainfall and temperature using different approaches. An approach that was utilized was the analysis of variations of the mean of these variables and the shape of their statistical distribution [16,17]. This approach affords the advantage of simplicity in the use and interpretation of results. The absence of effectively accessible daily data and large data gaps constrain the use of this approach in data analysis over varied locations in Africa [9]. Through international collaborations, this challenge is being addressed with revived research interests in this purview [1].

Even though knowledge of climate extremes is required to develop and manage emergencies such as flood and drought, regions with data scarcity and without quality controlled meteorological data had few studies regarding the analysis of climate extremes. This research gap raised concerns for interventions to help remedy the situation. Although, Expert Team on Climate Change Detection, Monitoring, and Indices (ETCCDMI) has aided in the quality control and analysis of climate data at the national level and regional level $[18,19]$ and the development of a set of suitable indices for climate extreme analysis [20-22], such a study is yet to be undertaken at the study location.

This paper examines the trend in annual rainfall and temperature extreme indices over the Vea catchment for the period 1985-2016 using the quality controlled station and gridded data. The specific objectives of the study are to; (i) evaluate the performance of Climate Hazards Group InfraRed Precipitation with Station (CHIRPS) data in reproducing the rainfall pattern of the study area (ii) examine the temporal trend and spatial variation in extreme rainfall and temperature indices over the catchment.

\section{Materials and Methods}

\subsection{Study Area}

The study area is the Vea catchment, one of the sub-catchments within the White Volta Basin (WVB) located between latitudes $10^{\circ} 30^{\prime} \mathrm{N}-11^{\circ} 08^{\prime} \mathrm{N}$ and longitudes $1^{\circ} 15^{\prime} \mathrm{W}-0^{\circ} 50^{\prime} \mathrm{E}$ (Figure 1 ). It has an area of about $305 \mathrm{~km}^{2}$ and covers mainly the Bongo and Bolgatanga districts in the Upper East region of Ghana with a small portion over the south-central part of Burkina Faso. The climate of the catchment 
is controlled by the movement of the Inter-tropical Discontinuity (ITD) over the land that dominates the climate of the entire West African region. Located in a semi-arid agro-climatic zone, the catchment covers three agro-ecological zones: the Savanna and Guinea Savanna zones in Ghana, and north Sudanian Savanna zone in Burkina Faso. The catchment is characterized by a uni-modal rainfall regime from April/May to October with a mean annual rainfall of about $957 \mathrm{~mm}$ which normally peaks in August and a uniformly high mean temperature of $28.9^{\circ} \mathrm{C}$ [23]. The catchment is characterized by fairly low relief with elevation ranging between $89 \mathrm{~m}$ and $317 \mathrm{~m}$. The land use/cover type at the area is mainly dominated by cropland (middle part of the catchment), grassland, and forest/mixed vegetation found at the south and northeastern part of the catchment. Agriculture, consisting of rain-fed and irrigated crops, is the main activity of the people at the catchment.

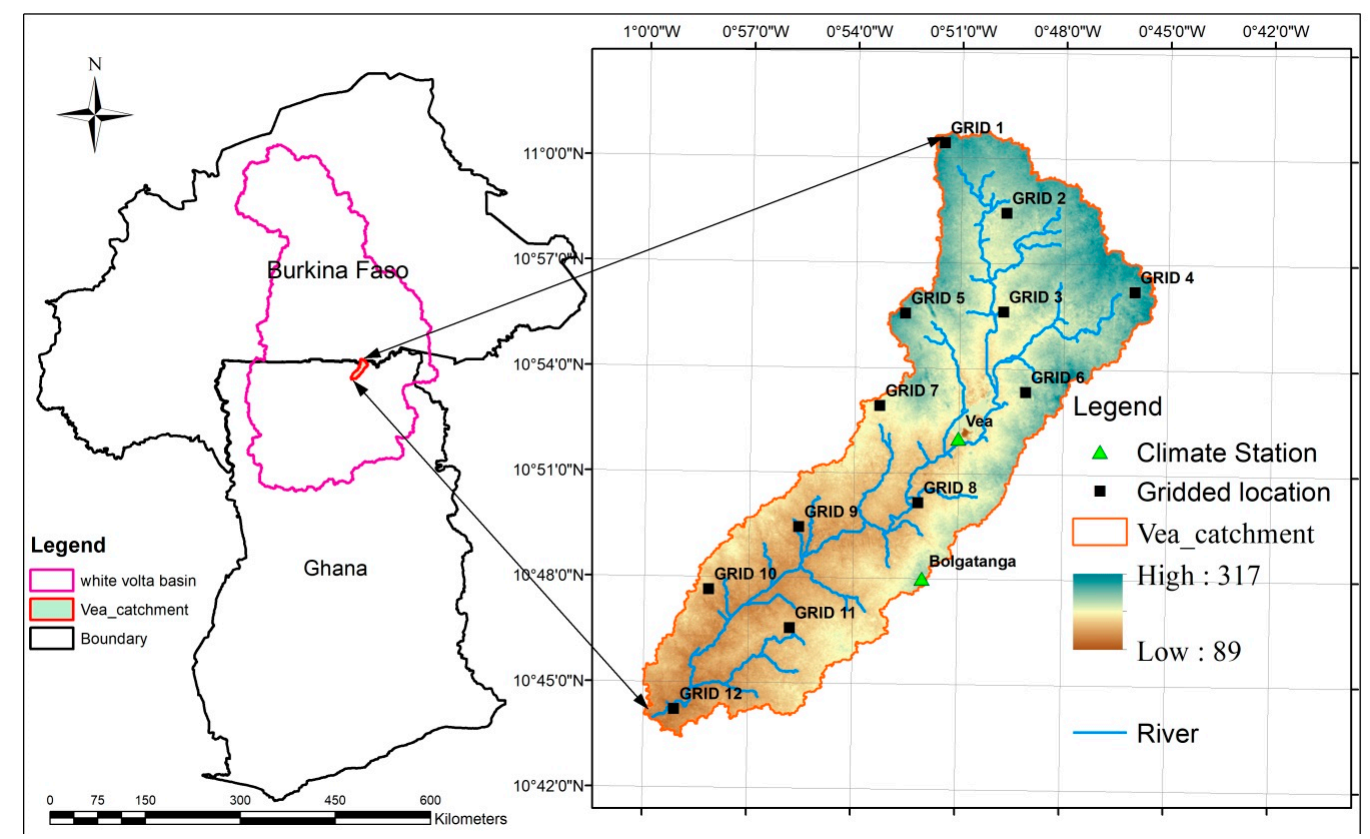

Figure 1. Map of the Vea catchment showing station and gridded precipitation locations within a $5 \mathrm{~km}$ grid.

\subsection{Climate Data, Quality Control, and Validation}

Historical daily rainfall, maximum and minimum temperature station data within the Vea catchment over the period 1990-2016 (Table 1) were obtained from the West African Science Service Center on Climate Change (WASCAL) research center. Due to missing rainfall and temperature data (less than 10\%) which were mostly found in the Bolgatanga station for the period 1986 to 1989, and the limited spatial distribution of climate stations within the catchment (Figure 1), and an additional twelve gridded) daily rainfall data (Table 1) from the Climate Hazards Group Infrared Precipitation with Station data (CHIRPS) for the period 1985-2016 were also used. These gridded locations (Figure 1) were selected to represent the three agro-ecological zones namely; the Savanna zone (GRID 3, GRID 4, GRID 5, GRID 6, GRID 7 and GRID 8), Guinea Savanna (GRID 9, GRID 10, GRID 11 and GRD 12) and the north Sudanian Savanna zone (GRID 1 and GRID 2) in the study area. The CHIRPS precipitation dataset is a product of the US Geological Survey (USGS) and the Climate Hazards Group at the University of California, Santa Barbara (UCSB) which is available on daily timescale at a $5 \mathrm{~km}$ spatial resolution [24] and was freely downloaded from (http://chg.geog.ucsb.edu/data/chirps). Quality control was checked for the two stations (Vea and Bolgatanga) using Microsoft excel and Rclimdex package. Missing data found in the Bolgatanga station were filled directly using the CHIRPS precipitation data and $0.5^{\circ}$ resolution daily minimum and maximum temperature data from the National Aeronautics and Space Administration Prediction of Worldwide Energy Resource 
(NASA POWER) project (https://power.larc.nasa.gov/data-access-viewer/). A homogeneity test using a single mass curve was performed on the data to ensure that the observed variations in the data series are resulting from fluctuations in weather and climate exclusively.

Table 1. Climate data used from the period 1985-2016.

\begin{tabular}{ccc}
\hline ID & Data Type (Name) & Variables \\
\hline 1 & Gridded (GRID 1) & Rainfall \\
2 & Gridded (GRID 2) & Rainfall \\
3 & Station (Vea) & rainfall and temperature \\
4 & Gridded (GRID 3) & Rainfall \\
5 & Station (Bolgatanga) & rainfall and temperature \\
6 & Gridded (GRID 4) & Rainfall \\
7 & Gridded (GRID 5) & Rainfall \\
8 & Gridded (GRID 6) & Rainfall \\
9 & Gridded (GRID 7) & Rainfall \\
10 & Gridded (GRID 8) & Rainfall \\
11 & Gridded (GRID 9) & Rainfall \\
12 & Gridded (GRID 10) & Rainfall \\
13 & Gridded (GRID 11) & Rainfall \\
14 & Gridded (GRID 12) & Rainfall \\
\hline
\end{tabular}

Validation of the CHIRPS precipitation data was performed on monthly and annual scales by the comparison of the extracted point-based CHIRPS data for the Vea and Bolgatanga locations with the Vea and Bolgatanga stations data for the period 1990-2016 due to some missing gaps for bolgatanga station from 1986 to 1989. The performance of the CHIRPS precipitation data was assessed using several statistical indicators such as Pearson correlation coefficient ( $r$ ), percentage bias (PBIAS), standard deviation, the root mean square error (RMSE) and Nash-Sutcliff coefficient (NSE) to verify the acceptability of CHIRPS data for further analysis at the catchment.

\subsection{Climate Parameters Analysis}

\subsubsection{Standardized Anomaly Index}

An investigation of the frequency of dry and wet years over the period of 1985-2016 was conducted using the Standardized Anomaly Index (SAI). SAI is a measure of deviation, in standard units, between a data value and its mean. According to the study of [25], the index is used as a descriptor of rainfall variability and it indicates the number of standard deviations that a rainfall event deviates from the average of the years considered. The classification scheme (Table 2) suggested by the study of [26] was used to determine wet or dry intensity over the study area. The Standardized Anomaly Index is calculated as:

$$
S A I=\frac{(x-\mu)}{\sigma}
$$

where $x$ is the annual precipitation, $\mu$ is the long-term mean and $\sigma$ is its standard deviation.

Table 2. Classification Scale for wetness and dryness.

\begin{tabular}{cc}
\hline Classification & Values \\
\hline Extremely wet & 2.00 and more \\
Very wet & 1.50 to 1.99 \\
Moderately wet & 1.00 to 1.49 \\
Normal & -0.99 to 0.99 \\
Moderately dry & -1.00 to -1.49 \\
Very dry & -1.50 to -1.99 \\
Extremely dry & -2.00 and less \\
\hline \multicolumn{2}{c}{ Source: $[25]}$.
\end{tabular}




\subsubsection{Extreme Climate Indices}

Climate Indices calculation based on daily time series of temperature and rainfall is one of the ways of characterizing the intensity, duration, and frequency of climate extremes [27,28]. Several indicators (Table 3) have been established by the Expert Team on Climate Change Detection Monitoring Indices (ETCCDMI) for understanding climate extremes and trends in several regions [29,30]. These Indices were computed on the interface of R software using RClimdex developed by ETCCDMI which is freely downloaded from (http:/ / cccma.seos.uvic.ca/ETCCDMI/index.shtml). The detailed description of the selected rainfall and temperature indices used for this study are shown in Table 3. These indices are primarily based on station-level thresholds and percentile computed from a common thirty (30) year base period of 1986-2015. The various extreme climate indices computed were analyzed spatially using the deterministic Inverse Distance Weighted (IDW) interpolation technique which has been demonstrated to perform well in spatial rainfall distribution [31]. The spatial interpolation by IDW is performed with the assumption that the attribute value of an unknown location is the weighted average of a known location by assigning values to the unknown location using values from known neighboring locations based on the concept of distance weighting.

Table 3. Climate Extreme Indices.

\begin{tabular}{|c|c|c|c|}
\hline \multicolumn{4}{|c|}{ (A) Precipitation Indices } \\
\hline Indices & Descriptive Name & Definition & Units \\
\hline PRCPTOT & Annual total wet-day precipitation & Annual total rainfall from days $\geq 1 \mathrm{~mm}$ & $\mathrm{~mm}$ \\
\hline R95p & Very wet days & $\begin{array}{l}\text { Annual total precipitation from the days with daily } \\
\text { rainfall }>95 \text { th percentile }\end{array}$ & $\mathrm{mm}$ \\
\hline R99p & Extremely wet days & $\begin{array}{l}\text { Annual total precipitation on the days when daily } \\
\text { rainfall }>99 \text { th percentile }\end{array}$ & $\mathrm{mm}$ \\
\hline $\mathrm{R} 20 \mathrm{~mm}$ & Number of very heavy precipitation days & Annual counts of days when rainfall $\geq 20 \mathrm{~mm}$ & days \\
\hline $\mathrm{R} 10 \mathrm{~mm}$ & Number of heavy precipitation days & Annual counts of days when rainfall $\geq 10 \mathrm{~mm}$ & days \\
\hline RX1day & Max 1-day precipitation amount & Annual maximum 1-day precipitation & $\mathrm{mm}$ \\
\hline RX5day & Max-5-day precipitation amount & Annual maximum consecutive 5-day rainfall & $\mathrm{mm}$ \\
\hline CWD & Consecutive wet days & $\begin{array}{l}\text { Maximum number of consecutive days with } \\
\text { rainfall } \geq 1 \mathrm{~mm}\end{array}$ & days \\
\hline CDD & Consecutive dry days & $\begin{array}{l}\text { Maximum number of consecutive days with } \\
\text { rainfall }<1 \mathrm{~mm}\end{array}$ & days \\
\hline SDII & Simple daily intensity index & $\begin{array}{l}\text { Annual total rainfall when }(\mathrm{PRCP} \geq 1 \mathrm{~mm}) \text { divided } \\
\text { by the number of wet days }\end{array}$ & $\mathrm{mm} /$ day \\
\hline \multicolumn{4}{|c|}{ (B) Temperature Indices } \\
\hline Indices & Descriptive Name & Definition & Units \\
\hline TX90p & Warm days & Percentage of days when Tmax $>$ 90th percentile & Days \\
\hline TN90p & Warm nights & Percentage of days when Tmin $>$ 90th percentile & Days \\
\hline TX10p & Cool days & Percentage of days when Tmax $<10$ th percentile & Days \\
\hline TN10p & Cool night & Percentage of days when Tmin $<10$ th percentile & Days \\
\hline $\mathrm{TXx}$ & Warmest day & $\begin{array}{l}\text { Annual maximum value of the daily } \\
\text { max temperature }\end{array}$ & ${ }^{\circ} \mathrm{C}$ \\
\hline $\mathrm{TNx}$ & Warmest night & Annual maximum value of daily min temperature & ${ }^{\circ} \mathrm{C}$ \\
\hline WSD1 & Warm spell duration & $\begin{array}{l}\text { Annual count of days with at least } 6 \text { consecutive } \\
\text { days with Tmax }>90 \text { th percentile }\end{array}$ & Days \\
\hline
\end{tabular}

\subsubsection{Trend Analysis of Rainfall and Temperature Indices}

A non-parametric Mann-Kendall (MK) test and Sen's slope estimator were used for trend detection and quantification in the extremes climate indices that were computed using the MAKESENS software. The MK test (Equations (2)-(5)), a widely used statistical analysis for trend detection in extreme climate indices and hydro-climate analysis $[30,32]$ assumes a null hypothesis $\left(\mathrm{H}_{\mathrm{o}}\right)$ that there is no trend which is tested against the alternative hypothesis $\left(\mathrm{H}_{1}\right)$ of the presence of a trend [33].

$$
S=\sum_{k=1}^{n-1} \sum_{j=k+1}^{n} \operatorname{Sgn}\left(X_{j}-X_{k}\right)
$$


where $X_{j}$ and $X_{k}$ are sequential data values for the time series data of length $n$. The sum of the $S g n$ function and the mean-variance $\operatorname{Var}(\operatorname{Smk})$, under the null hypothesis $\left(\mathrm{H}_{\mathrm{o}}\right)$ of no trend and independence of the series terms are given in Equations (3) and (4) respectively.

$$
\begin{gathered}
\operatorname{Sgn}\left(X_{j}-X_{k}\right)=\left\{\begin{array}{c}
1 \text { if } X_{j}>X_{k} \\
0 \text { if } X_{j}=X_{k} \\
-1 \text { if } X_{j}<X_{k}
\end{array}\right. \\
\operatorname{Var}\left(S_{m k}\right)=\frac{N(N-1)(2 N+5)-\sum_{i=1}^{m} U_{i}(i)(i-1)(2 i+5)}{18}
\end{gathered}
$$

where $N$ is the length of the data set, $m$ is the number of tied groups and $U_{i}$ denotes the size of the $M$ th group. The standard normal test statistic $Z_{S}$ (Equation (5)) indicates a trend in the data series with a positive or negative value indicating increasing or decreasing trends respectively. The trend result was evaluated at $5 \%$ significant level (corresponding threshold value of \pm 1.96 ) and the null hypothesis $\left(\mathrm{H}_{\mathrm{o}}\right)$ that there is no trend is rejected when $/ Z_{S} / \geq Z_{\alpha / 2}$ at $\alpha=0.05$ level of significance. The magnitude of the trend was estimated using the Theil-Sen's estimator (Equations (6) and (7)) initially proposed by Sen [34] and modified by [35].

$$
\begin{gathered}
Z_{s}=\left\{\begin{array}{c}
\frac{S-1}{\sqrt{V A R(S)}}, \text { for } s>0 \\
0, \text { for } s=0 \\
\frac{S+1}{\sqrt{\text { VAR }(S)}}, \text { for } s<0
\end{array}\right. \\
Q_{i}=\frac{\left(X_{j}-X_{k}\right)}{(j-k)} \text { for all } k<j \text { and } i=1, . . N \\
Q_{\text {med }}=\left\{\begin{array}{c}
Q\left[\frac{(n+1)}{2}\right], \text { where } N \text { is odd } \\
Q\left(\frac{N}{2}\right)+Q\left[\frac{N+2}{2}\right], \text { where } N \text { is even }
\end{array}\right.
\end{gathered}
$$

where $Q_{i}$ is the slope between data points $X_{j}$ and $X_{k}, Q_{\text {med }}$ is median slope estimator which reflects the direction of the trend in the data.

\section{Results}

\subsection{Rainfall Analysis for the Vea Catchment}

\subsubsection{Station and Gridded Precipitation Data Comparison}

The results of the comparison between the CHIRPS gridded precipitation data and the station rainfall data at both mean monthly and annual scales in reproducing the current rainfall pattern of the Vea and Bolgatanga stations for the period 1990-2016 are shown in Figure 2. The CHIRPS precipitation data for both stations showed a unimodal rainfall pattern with the peak of the raining season in August which is similar to the station data. The statistical analysis result at both monthly and annual scales is shown in Table 4. At the monthly scale, a very high agreement with the station data was observed with a correlation coefficient $(r=0.99)$, and a Nash-Sutcliffe efficiency of 0.98 for both Vea and Bolgatanga locations. The CHIRPS data simulated well the seasonal rainfall pattern with a slight overestimation at the peak month (August) of the raining season at the Vea station. At annual scale, although there was an underestimation of the inter-annual variability or standard deviation (Figure 2C,D) by the CHIRPS data at both stations, however the variability in rainfall was captured well for the two locations. The CHIRPS precipitation data was able to reproduce the mean monthly rainfall patterns for the two stations compared to the mean annual rainfall patterns as shown in Figure 2. This can be attributed to the higher correlation at monthly scale compared to annual scale. The percentage bias (PBIAS) indicated an overestimation at Vea station $(6.7 \%)$ and underestimation at 
Bolgatanga station $(-1.1 \%)$ but in an acceptable range with PBIAS within \pm 25 as indicated by [36]. In general, the observed statistical results demonstrate that the CHRIPS precipitation data is able to reproduce the rainfall pattern of the Vea catchment and therefore can be used for further analysis.

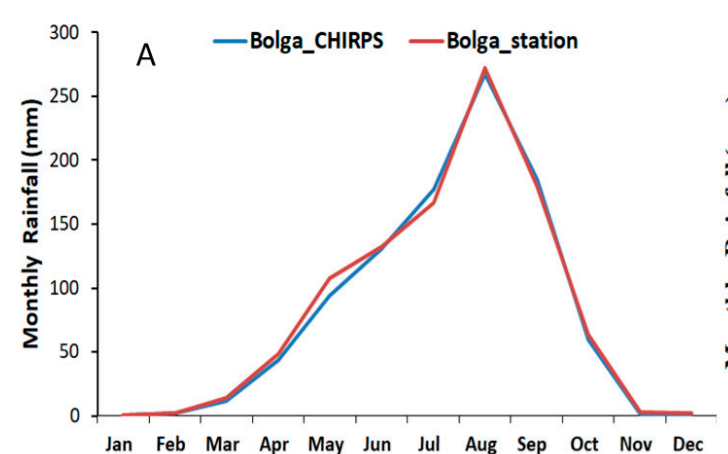

an Feb Mar Apr May Jun Jul Aug Sep Oct Nov Dec

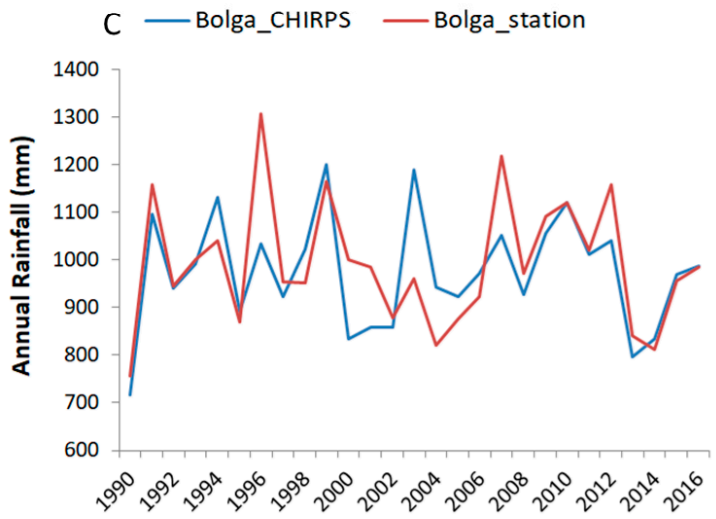

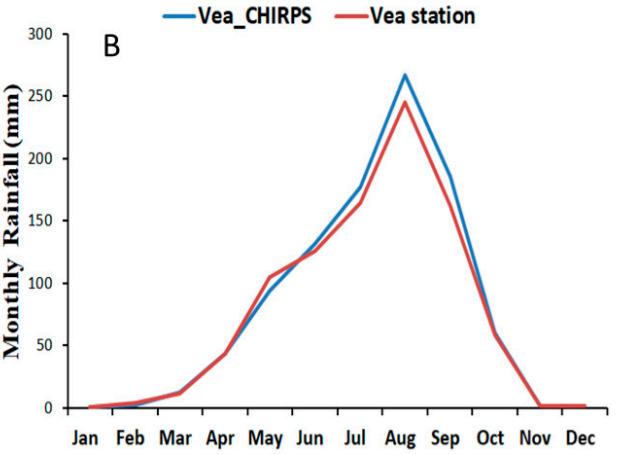

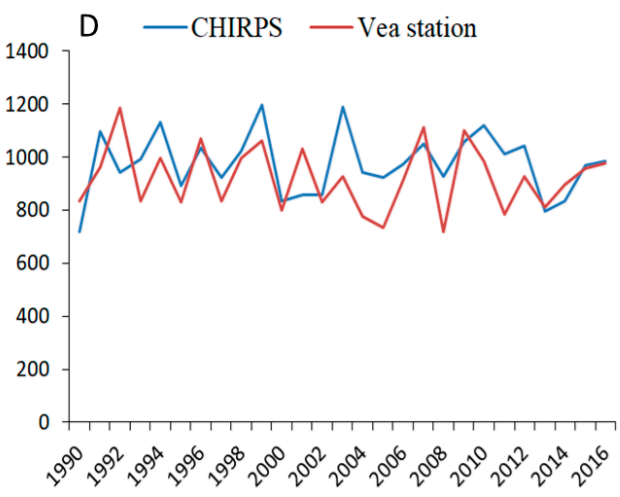

Figure 2. Performance evaluation of Climate Hazards Group InfraRed Precipitation with Station (CHIRPS) based on mean monthly distribution (A,B) and annual distribution (C,D) of rainfall from 1990 to 2016 for the Vea and Bolgatanga locations.

Table 4. Mean monthly and annual scale statistical analysis of rainfall for the station and CHIRPS data from 1990 to 2016 in the catchment.

\begin{tabular}{ccc}
\hline Monthly Scale & Vea & Bolgatanga \\
\hline Percentage bias (PBIAS) & $4.4 \%$ & $-8.1 \%$ \\
Pearson correlation coefficient (r) & 0.99 & 0.99 \\
Root-mean-square error (RMSE) Nash-Sutcliffe efficiency & 6.6 & 3.9 \\
& 0.98 & 0.99 \\
\hline Annual Scale & & \\
\hline Percentage bias (PBIAS) & $6.7 \%$ & $-1.1 \%$ \\
Pearson correlation coefficient (r) & 0.50 & 0.70 \\
Mean annual rainfall (mm) & 921.8 & 991.4 \\
& $(974.9)$ & $(974.8)$ \\
Standard deviation & 123.3 & 132.9 \\
& $(117.8)$ & $(118.1)$ \\
\hline
\end{tabular}

NB: the values for the CHIRPS data are in the bracket.

\subsubsection{Standardized Anomaly Index of Annual Rainfall}

The results of the Standardized Anomaly Index (SAI) analysis of annual rainfall for both the entire catchment and for the individual locations are shown in Figure 3. At catchment scale (Figure 3P), 47\% negative anomalies compared to $53 \%$ positive anomalies were observed during the period 1985 to 2016 . The years 1990 and 2013 were observed to be the most extremely dry years, while 1999 and 2003 were 
the most extremely wet period. The years 1989, 1991, 1994, and 2010 were seen as moderately wet (SAI is greater than 1.49) for the most, while 2000 and 2014 were moderately dry periods. At individual scale (Figure $3 \mathrm{~A}-\mathrm{N}$ ), shows variability in wetter than normal and drier than normal periods. About $57 \%$ of the locations indicate higher percentage $(>50 \%)$ of wetter than normal period (SAI greater than 0.99$)$, $14.3 \%$ of locations indicating drier than normal period and $28.6 \%$ of locations shows equal distribution of wet and dry periods. The distributions of wetter and drier than normal periods for the individual rainfall locations and the entire catchment are shown in Table 5.

Table 5. Distribution of wetter and drier periods for the different locations within the Vea catchment.

\begin{tabular}{ccccc}
\hline Rainfall Location & $\begin{array}{c}\text { Frequency of } \\
\text { Drier than Normal }\end{array}$ & $\begin{array}{c}\text { Frequency of Wetter } \\
\text { than Normal }\end{array}$ & \% of Dry Period & \% of Wet Period \\
\hline GRID 1 & 4 & 5 & 44.4 & 55.6 \\
GRID 2 & 5 & 5 & 50.0 & 50.0 \\
VEA & 4 & 4 & 50.0 & 50.0 \\
GRID 3 & 6 & 6 & 50.0 & 50.0 \\
GRID 4 & 5 & 4 & 45.5 & 54.5 \\
GRID 5 & 6 & 5 & 60.0 & 40.0 \\
GRID 6 & 6 & 6 & 54.5 & 45.5 \\
GRID 7 & 6 & 6 & 50.0 & 50.0 \\
GRID 8 & 3 & 6 & 33.3 & 66.7 \\
GRID 9 & 5 & 5 & 54.5 & 54.5 \\
GRID 10 & 6 & 6 & 45.5 & 45.5 \\
GRID 11 & 5 & 6 & 45.5 & 54.5 \\
GRID 12 & 5 & 7 & 36.4 & 54.5 \\
BOLGATANGA & 4 & 6 & 45.5 & 63.6 \\
CATCHMENT & 5 & & & 54.5 \\
\hline
\end{tabular}
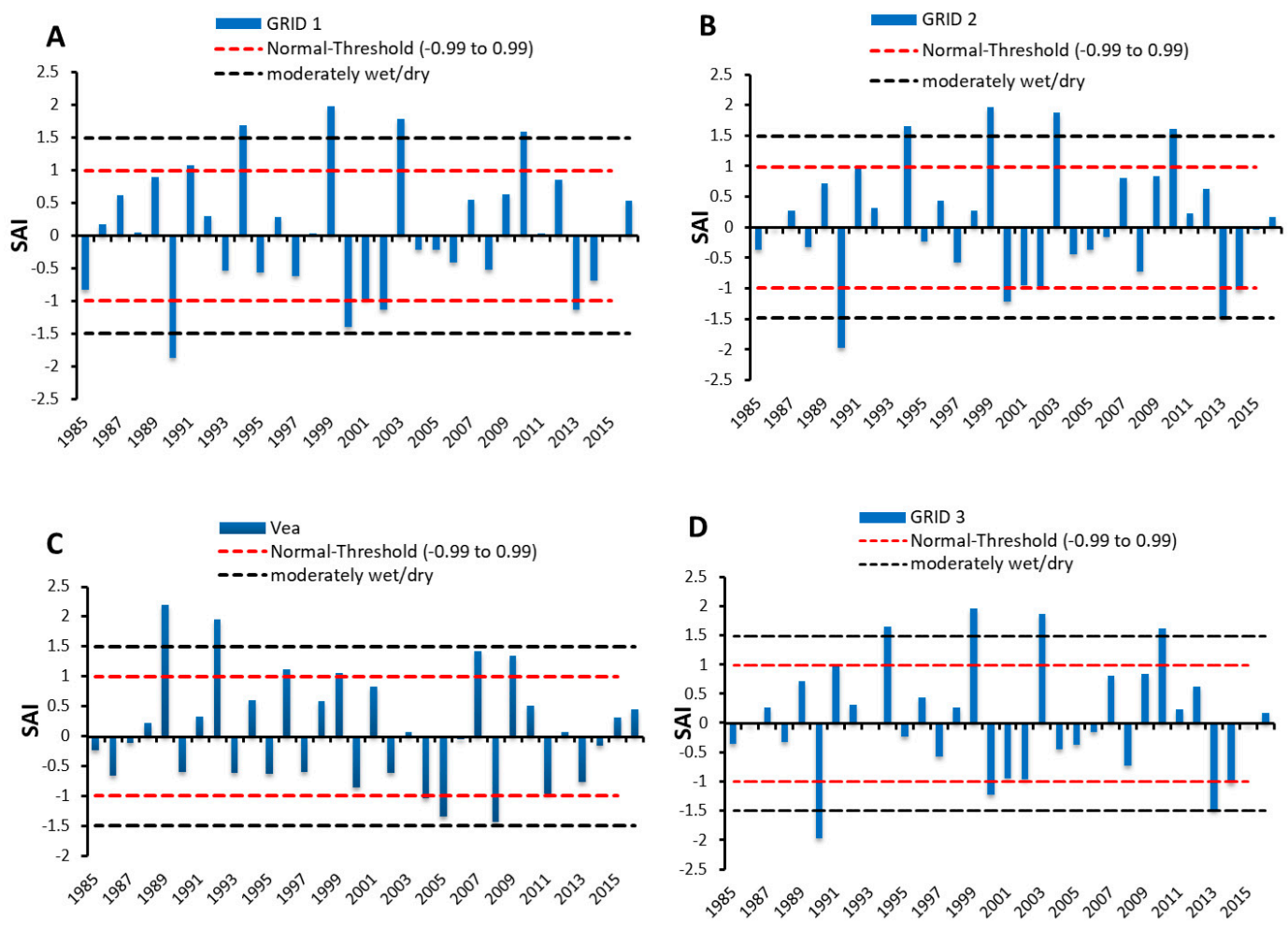

Figure 3. Cont. 

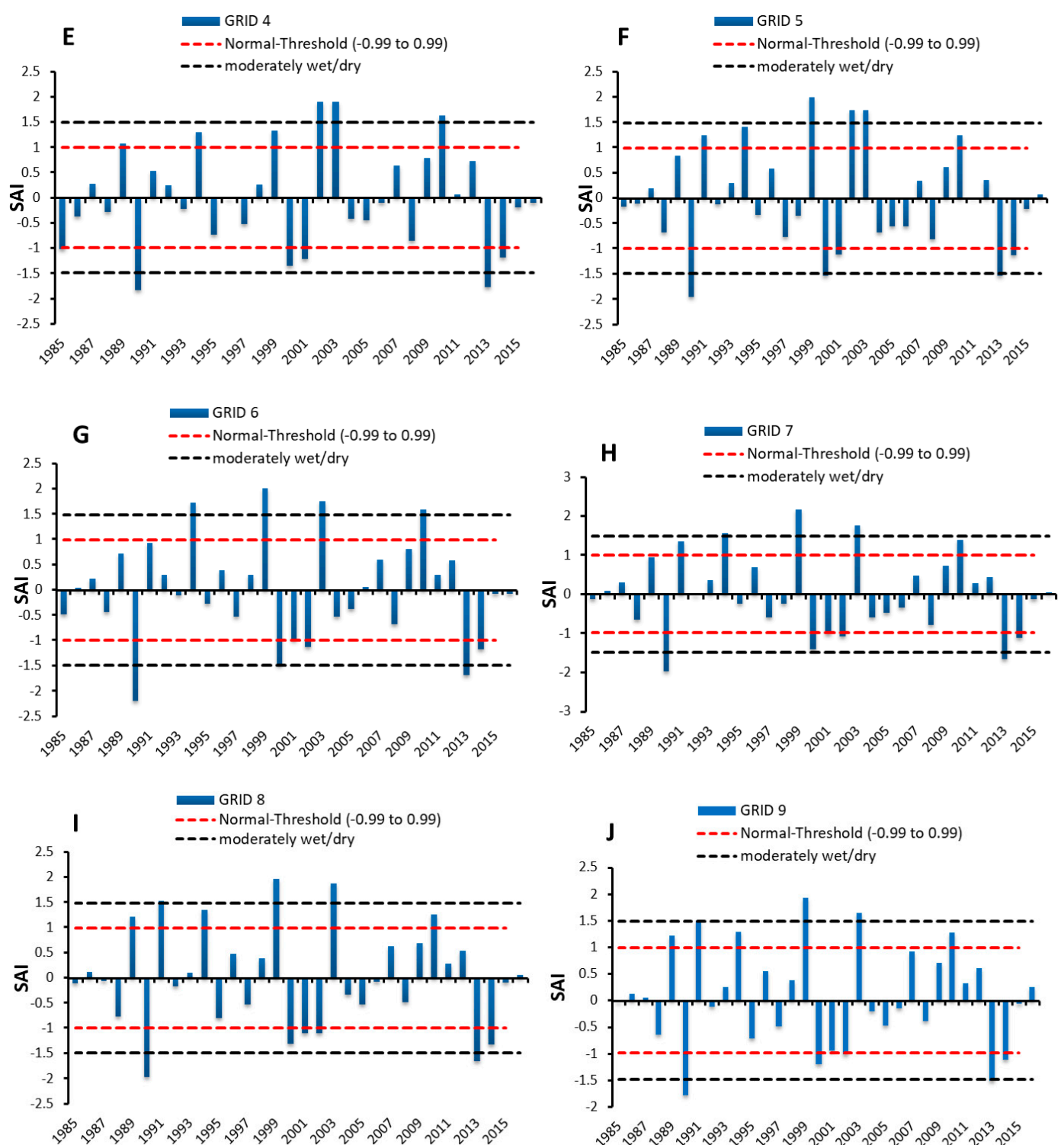

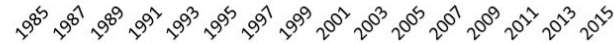

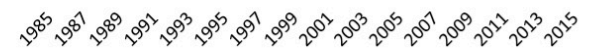
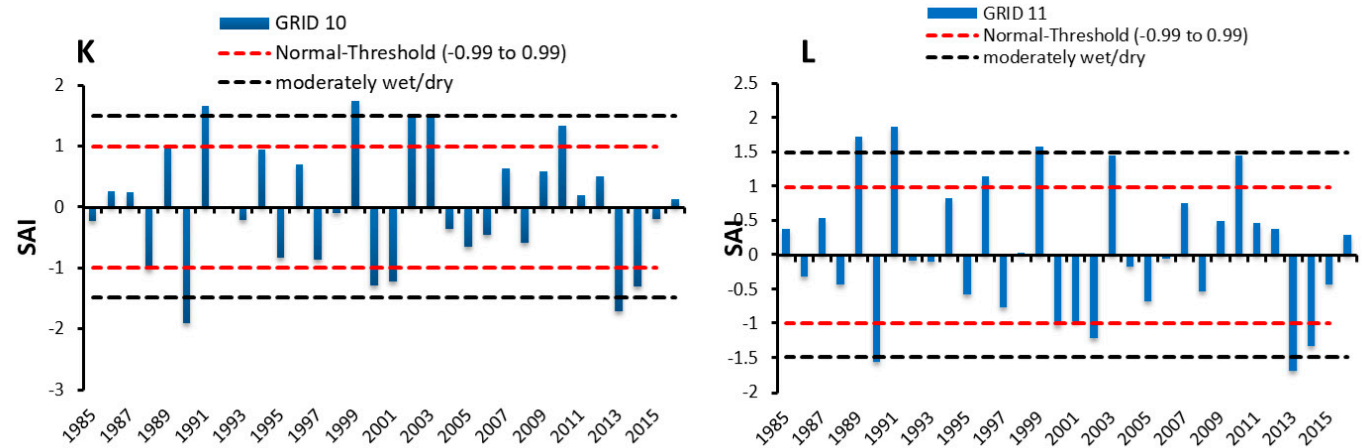

Figure 3. Cont. 

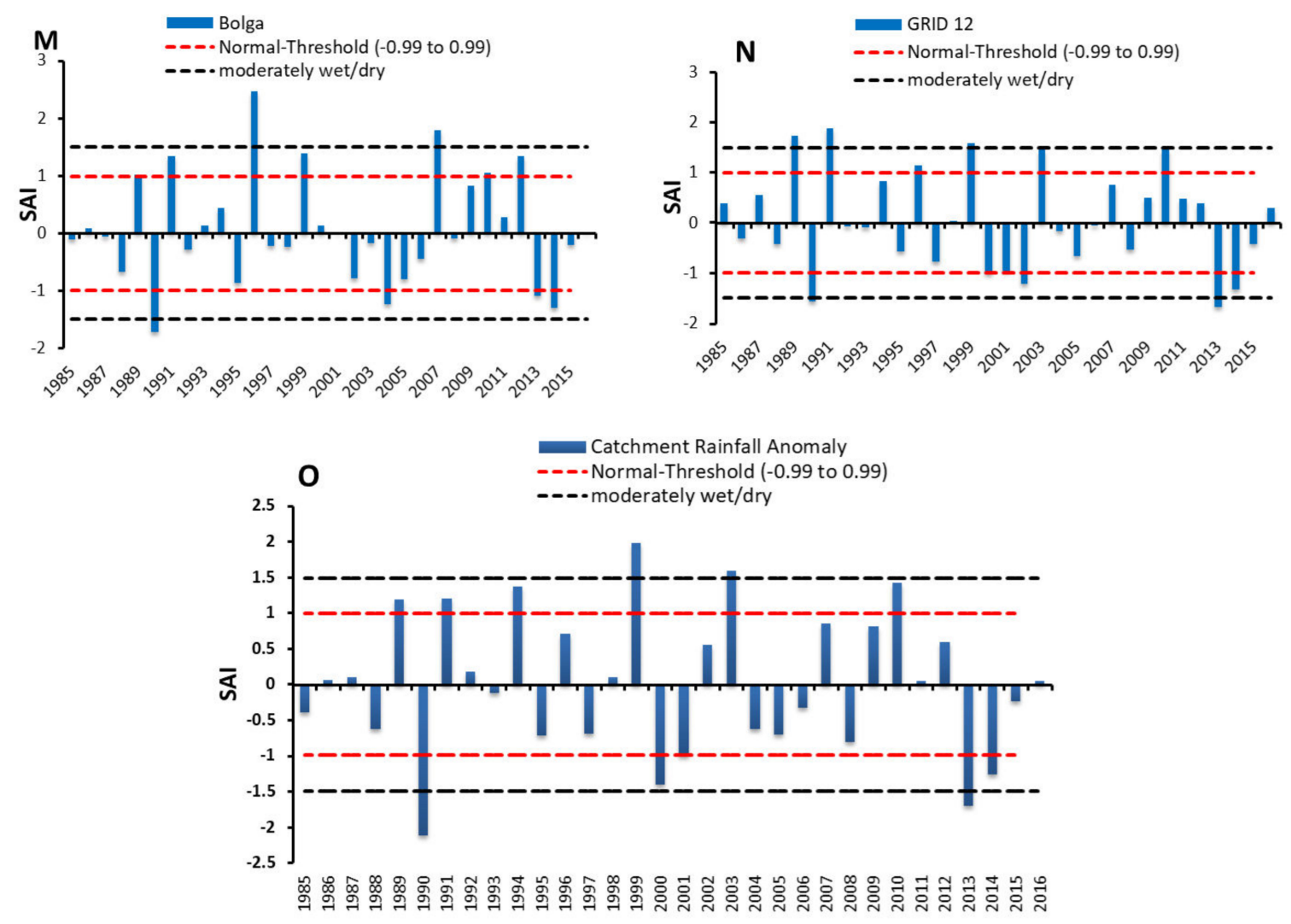

Figure 3. Mean Annual Standardized Anomaly Index from 1985 to 2016 for the individual locations $(\mathbf{A}-\mathbf{N})$ and Catchment Scale (O).

\subsubsection{Spatio-Temporal Trend Analysis of Rainfall Extremes}

(a) Rainfall Intensity Indices

The spatial distributions and MK test statistics for the time series of rainfall intensity indices (PRCPTOT, RX1day, RX5day, R95P, R99P, and SDII) for the individual rainfall locations (station and gridded) and the entire catchment over the period 1985-2016 are shown in Figure 4 and Table 6 respectively. The trend in annual total wet-day precipitation (PRCPTOT), annual maximum 1-day precipitation (RX1day), annual maximum 5-day precipitation (RX5day), and very wet days (R95P) were observed to decrease for most of the rainfall locations (78\%) with the exception of the upper part of the Vea catchment (GRID 1) that shows an increasing trend in all locations. The Intensity indices for the upper Vea location (GRID 1) were found to be increasing though not statistically significant at $5 \%$ level. Besides, the Vea station that recorded a decreasing rate of $2.8 \mathrm{~mm} /$ year, the magnitude of decreasing PRCPTOT for the other locations were quite negligible and not statistically significant. At the catchment scale, as shown in Table 6, a general decreasing trend in all the rainfall intensity indices was observed with the exception of Simple daily intensity index (SDII) that shows no trend. The spatial distribution of rainfall intensity indices (Figure 4) indicates that PRCPTOT is in the range of $914 \mathrm{~mm}$ to $990 \mathrm{~mm}$ and was found to be lowest at the central and extreme northeastern part of the Vea catchment. RX1day, RX5day, and SDII, on the other hand, were found to higher at the south eastern part of the catchment but lower in the northern and southwestern part of the catchment. 
Table 6. Mann-Kendall (MK) Trend Statistics of Rainfall Extreme Indices.

\begin{tabular}{|c|c|c|c|c|c|c|c|c|c|c|c|c|}
\hline \multirow{2}{*}{ Indices } & \multicolumn{2}{|c|}{ Vea } & \multicolumn{2}{|c|}{ Bolgatanga } & \multicolumn{2}{|c|}{ GRID 1} & \multicolumn{2}{|c|}{ GRID 2} & \multicolumn{2}{|c|}{ GRID 3} & \multicolumn{2}{|c|}{ GRID 4} \\
\hline & $Z$ & Slope & $Z$ & Slope & $Z$ & Slope & $Z$ & Slope & $Z$ & Slope & $Z$ & Slope \\
\hline PRCPTOT & -1.18 & -2.81 & -0.57 & -1.46 & 0.03 & 0.08 & -0.10 & -0.13 & -0.11 & -0.38 & 0.32 & 0.68 \\
\hline R95p & $\begin{array}{l}-2.48 \\
*\end{array}$ & -3.71 & -0.24 & -0.25 & 0.02 & 0.07 & -0.39 & -0.74 & -1.15 & -1.46 & -0.78 & -1.65 \\
\hline R99p & -1.13 & 0.00 & 0.15 & 0.00 & -0.07 & 0.00 & -0.56 & 0.00 & -1.43 & 0.00 & -1.05 & 0.00 \\
\hline $\mathrm{R} 10 \mathrm{~mm}$ & -0.47 & -0.20 & 1.04 & 0.11 & -0.24 & 0.00 & -0.18 & 0.00 & 1.06 & 0.12 & 0.39 & 0.00 \\
\hline $\mathrm{R} 20 \mathrm{~mm}$ & -1.62 & -0.10 & 0.26 & 0.00 & -0.20 & 0.00 & -0.41 & 0.00 & 0.62 & 0.00 & 0.84 & 0.04 \\
\hline RX1day & -2.51 & -0.77 & -0.23 & -0.06 & 0.57 & 0.09 & -0.52 & -0.18 & -0.96 & -0.19 & -0.86 & -0.19 \\
\hline RX5day & -1.43 & -0.75 & 0.39 & 0.11 & 0.21 & 0.07 & -0.10 & -0.06 & -0.32 & -0.16 & -1.07 & -0.34 \\
\hline CDD & -1.18 & -1.53 & 1.48 & 1.09 & 0.94 & 0.57 & 0.73 & 0.50 & 0.19 & 0.69 & 0.37 & 0.35 \\
\hline CWD & 0.87 & 0.00 & -1.33 & -0.04 & -0.85 & 0.00 & 0.10 & 0.00 & -0.24 & 0.00 & 0.62 & 0.00 \\
\hline SDII & $\begin{array}{c}-2.87 \\
*\end{array}$ & -0.13 & 0.47 & 0.03 & 0.19 & 0.03 & -1.56 & -0.02 & 0.78 & 0.54 & -0.47 & -0.01 \\
\hline \multirow{2}{*}{ Indices } & \multicolumn{2}{|c|}{ GRID 5} & \multicolumn{2}{|c|}{ GRID 6} & \multicolumn{2}{|c|}{ GRID 7} & \multicolumn{2}{|c|}{ GRID 8} & \multicolumn{2}{|c|}{ GRID 9} & \multicolumn{2}{|c|}{ GRID 10} \\
\hline & $Z$ & Slope & $Z$ & Slope & $Z$ & Slope & $Z$ & Slope & $Z$ & Slope & $Z$ & Slope \\
\hline PRCPTOT & -0.36 & -0.88 & -0.21 & -0.38 & -0.44 & -1.10 & 0.00 & 0.04 & -0.08 & -0.39 & -0.45 & -1.34 \\
\hline R95p & -0.39 & -0.65 & -0.66 & -1.37 & -0.97 & -1.60 & -1.77 & -2.23 & -0.94 & -0.23 & -1.30 & -2.37 \\
\hline R99p & -0.94 & 0.00 & -1.46 & -0.15 & $\begin{array}{c}-2.04 \\
*\end{array}$ & -1.59 & -0.46 & 0.00 & -0.54 & -0.22 & 0.00 & 0.00 \\
\hline $\mathrm{R} 10 \mathrm{~mm}$ & 0.52 & 0.04 & -0.08 & 0.00 & 0.57 & 0.04 & 0.59 & 0.07 & 0.00 & 0.00 & 0.55 & 0.05 \\
\hline $\mathrm{R} 20 \mathrm{~mm}$ & 0.53 & 0.00 & 0.10 & 0.00 & -0.18 & 0.00 & 0.65 & 0.03 & 1.41 & 0.14 & -0.23 & 0.00 \\
\hline RX1day & -0.84 & -0.20 & -0.83 & -0.09 & -1.80 & -0.39 & -0.36 & -0.10 & 0.38 & 0.00 & -0.37 & -0.09 \\
\hline RX5day & -0.31 & -0.17 & -0.16 & -0.05 & -0.78 & -0.26 & -0.31 & -0.16 & $1.96^{*}$ & 0.94 & 0.06 & 0.05 \\
\hline CDD & 0.62 & 0.35 & 0.41 & 0.33 & 1.20 & 0.71 & 1.48 & 0.92 & -1.63 & -0.04 & 2.08 & 1.26 \\
\hline CWD & -1.27 & 0.00 & -0.78 & 0.00 & -1.35 & 0.00 & -1.48 & -0.04 & -1.15 & -1.65 & -1.48 & -0.05 \\
\hline SDII & -0.29 & 0.00 & 0.00 & 0.00 & -0.50 & -0.01 & 0.15 & 0.00 & -0.71 & 0.00 & -0.59 & -0.01 \\
\hline \multirow{2}{*}{ Indices } & \multicolumn{2}{|c|}{ GRID 11} & \multicolumn{2}{|c|}{ GRID 12} & \multicolumn{2}{|c|}{ Catchment } & & & & & & \\
\hline & $Z$ & Slope & $Z$ & Slope & $Z$ & Slope & & & & & & \\
\hline PRCPTOT & -0.79 & -2.07 & -0.79 & -2.07 & -0.31 & -0.66 & & & & & & \\
\hline R95p & -1.93 & -3.59 & -1.93 & -3.59 & -0.08 & -0.22 & & & & & & \\
\hline R99p & -1.21 & 0.00 & -1.21 & 0.00 & -1.55 & -0.60 & & & & & & \\
\hline $\mathrm{R} 10 \mathrm{~mm}$ & 0.91 & 0.13 & 0.91 & 0.13 & 0.99 & 0.14 & & & & & & \\
\hline $\mathrm{R} 20 \mathrm{~mm}$ & 0.35 & 0.00 & 0.35 & 0.00 & 0.39 & 0.00 & & & & & & \\
\hline RX1day & -0.52 & -0.19 & -0.52 & -0.19 & -1.12 & -0.23 & & & & & & \\
\hline RX5day & -0.29 & -0.14 & -0.29 & -0.14 & -0.92 & -0.37 & & & & & & \\
\hline CDD & 1.17 & 0.61 & 1.17 & 0.61 & 0.29 & 0.18 & & & & & & \\
\hline CWD & -1.66 & -0.06 & -1.66 & -0.06 & -0.18 & 0.00 & & & & & & \\
\hline SDII & -0.85 & -0.02 & -0.85 & -0.02 & -0.26 & 0.00 & & & & & & \\
\hline
\end{tabular}

NB: * means statistically significant at 5\% level; - and + indicates decrease/increase trend respectively.

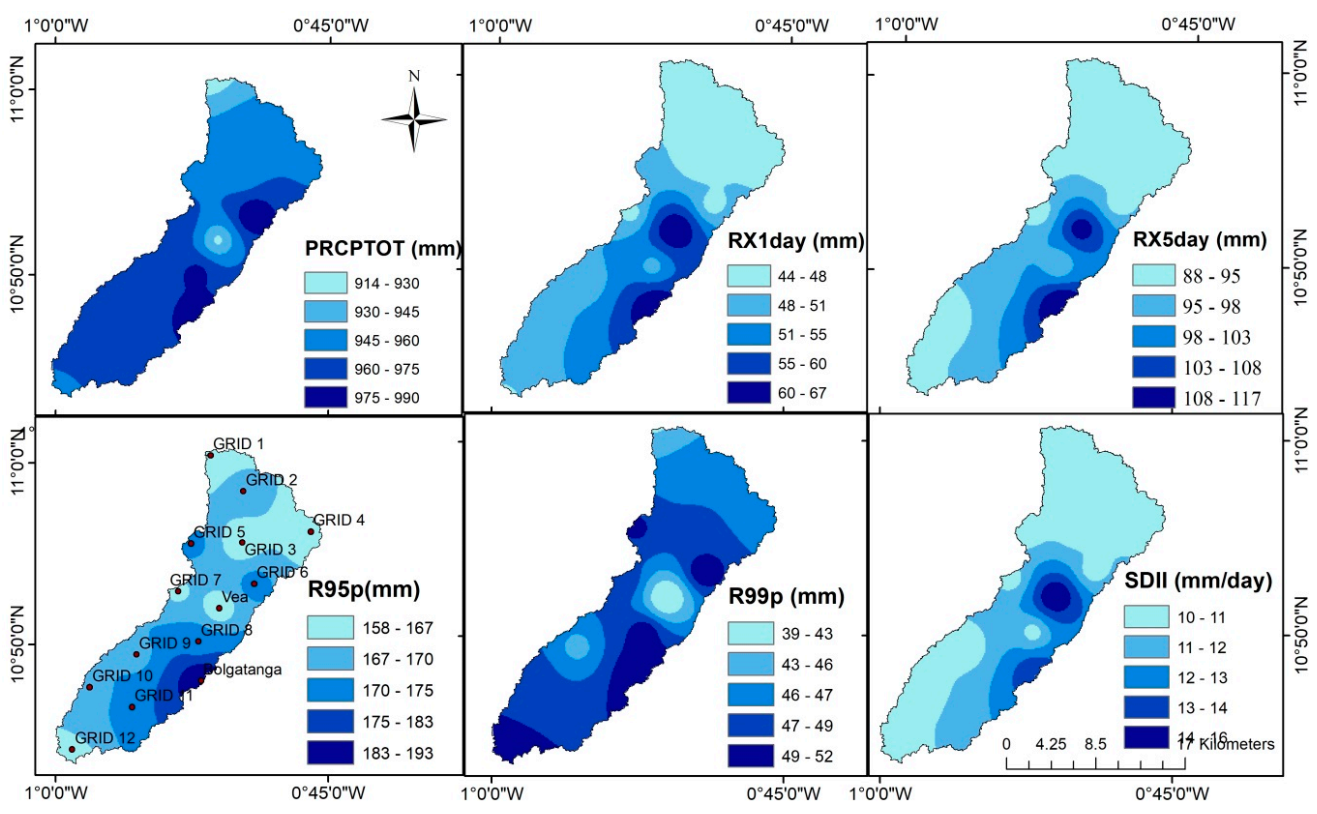

Figure 4. Spatial distribution of annual extreme rainfall intensity Indices. 
(b) Frequency Indicesvspace

The results of the temporal trend analysis statistics and spatial distribution of the frequency indices which consist of R10mm, R20mm, CWD, and CDD are shown in Table 6 and Figure 5 respectively. The temporal trend analysis based on Mann-Kendall test indicates a non-significant positive trends in the number of heavy precipitation days $(\mathrm{R} 10 \mathrm{~mm})$ and the number of very heavy precipitation days (R20mm) for most of the locations $(72 \%)$ and a decrease in trend for $28 \%$ of the locations. R20mm ranges from 30-38 days and was observed to be highest (36-38 days) at the eastern part of the catchment and lowest (30-33 days) at the central part (Vea station). On the other hand, R20mm which ranges from 10-16 days was found to be highest (14-16 days) at the central part (vea station) of the catchment. Similar results were noticed for the consecutive dry days (CDD) index which shows a non-significant increasing trend in $83 \%$ of the rainfall locations, with the exception of the Vea station that indicates a decreasing trend. Unlike the CDD, negative trends in consecutive wet days (CWD) were observed for $83 \%$ of the stations within the catchment. The spatial distribution of CWD (Figure 5a) ranges from 4 to 6 days with the highest number of days found at the upper and lower part of the catchment, while the lowest number of CWD is recorded at the Vea station. Like the CWD, a similar result was noticed for the number of days with heavy precipitation (R10mm) within the catchment. In general, most of the frequency indices as shown in Table 5 were observed to increase at the Vea catchment with the exception of CWD that shows a decrease, though not significant.

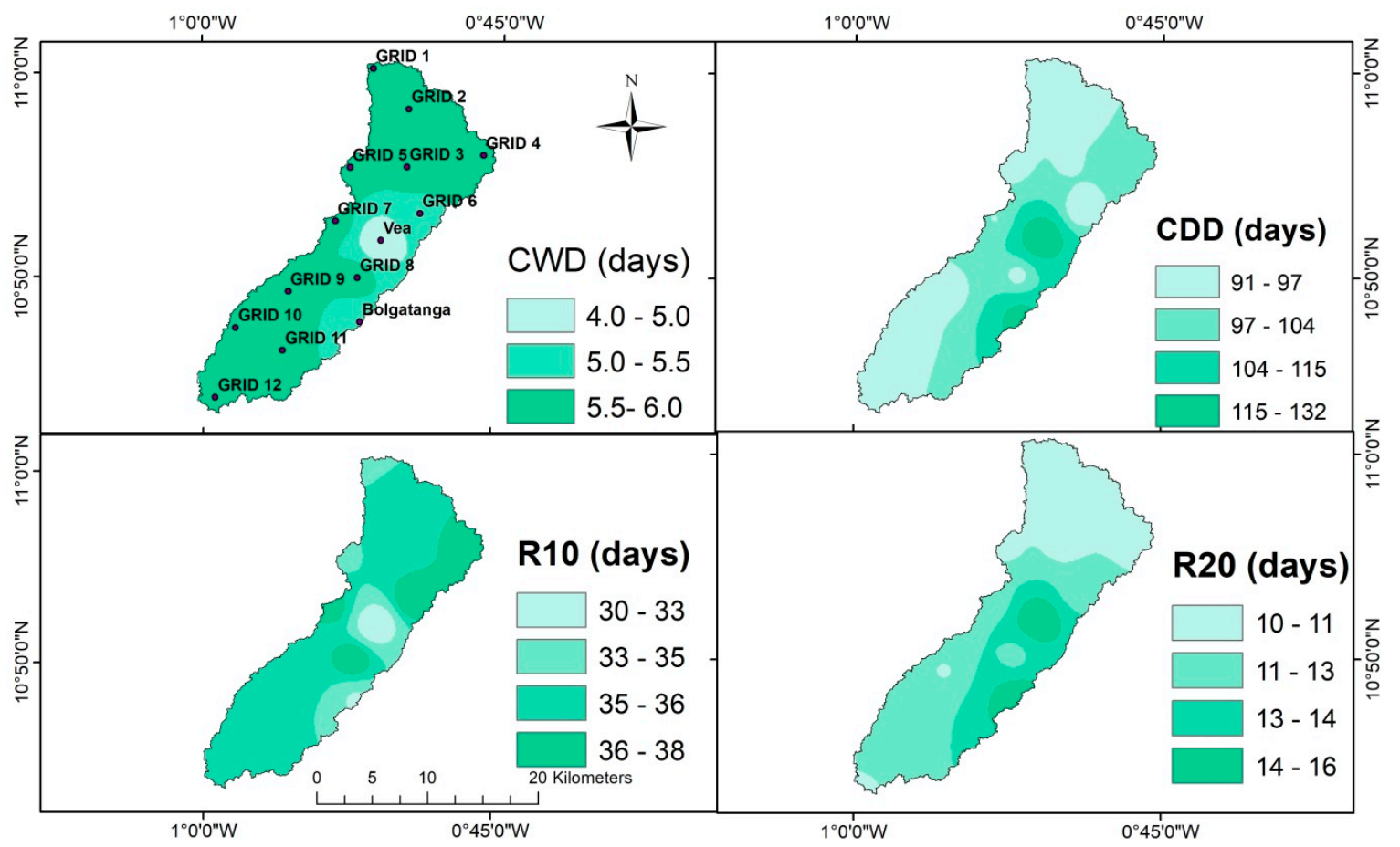

Figure 5. Spatial distribution of frequency of extreme rainfall Indices.

\subsection{Temperature Extreme Indices Trend Analysis}

The MK trend test results (Table 7) of temperature indices for the two stations (Vea and Bolgatanga) show a general warming trend over the Vea catchment from 1985 to 2016. The results show positive trends in the annual number of warm days (TX90p), warm nights (TN90p) and warm spells (WSDI) for both stations. TX90p ranges from 10 to 11 days with more warming at the southern part of the catchment (Figure 6) while TN90p shows higher days of warming during the night in the upper part of the catchment. The Bolgatanga station at the southern part of the catchment indicates a decrease in frequency of cool nights (TN10p), while the Vea station rather shows an increase. Cold days (TX10p) were observed to be increasing for both stations though not significant. The annual maximum value of 
daily minimum temperature or warmest night (TNx) was observed to be on an increase from 1985 to 2016 for both Vea and Bolgatanga stations. In the case of the annual maximum value of daily maximum temperature or warmest day (TXx), the Bolgatanga station was observed to be on a decrease at a rate of $0.28{ }^{\circ} \mathrm{C}$ per year while the Vea station is on an increase at a rate of $0.46^{\circ} \mathrm{C}$ per year. The spatial distribution of warmest days and nights (Figure 6) which ranges from 40 to 42 days (TXx) and 28 to 29 days (TNx) shows higher warming at the upper part of the catchment.

Table 7. MK trend test (Z) statistics and Sen's slope for temperature Indices.

\begin{tabular}{ccccc}
\hline \multirow{2}{*}{ Indices } & \multicolumn{2}{c}{ Vea } & \multicolumn{2}{c}{ Bolgatanga } \\
\cline { 2 - 5 } & $\boldsymbol{Z}$ & Slope & $\boldsymbol{Z}$ & Slope \\
\hline TX90p & 1.99 & 0.37 & 0.19 & 0.01 \\
TN90p & 0.51 & 0.11 & 1.56 & 0.56 \\
TX10p & 0.12 & 0.01 & 1.07 & 0.17 \\
TN10p & 0.94 & 0.11 & -0.15 & -0.02 \\
TXx & 0.46 & 0.01 & -0.28 & -0.01 \\
TNx & 0.07 & 0.04 & 1.15 & 0.03 \\
WSD1 & 0.90 & 0.00 & 1.27 & 0.00 \\
\hline
\end{tabular}

NB: * means statistically significant at $5 \%$ level; negative/positive value indicates, decrease/increase trend respectively.

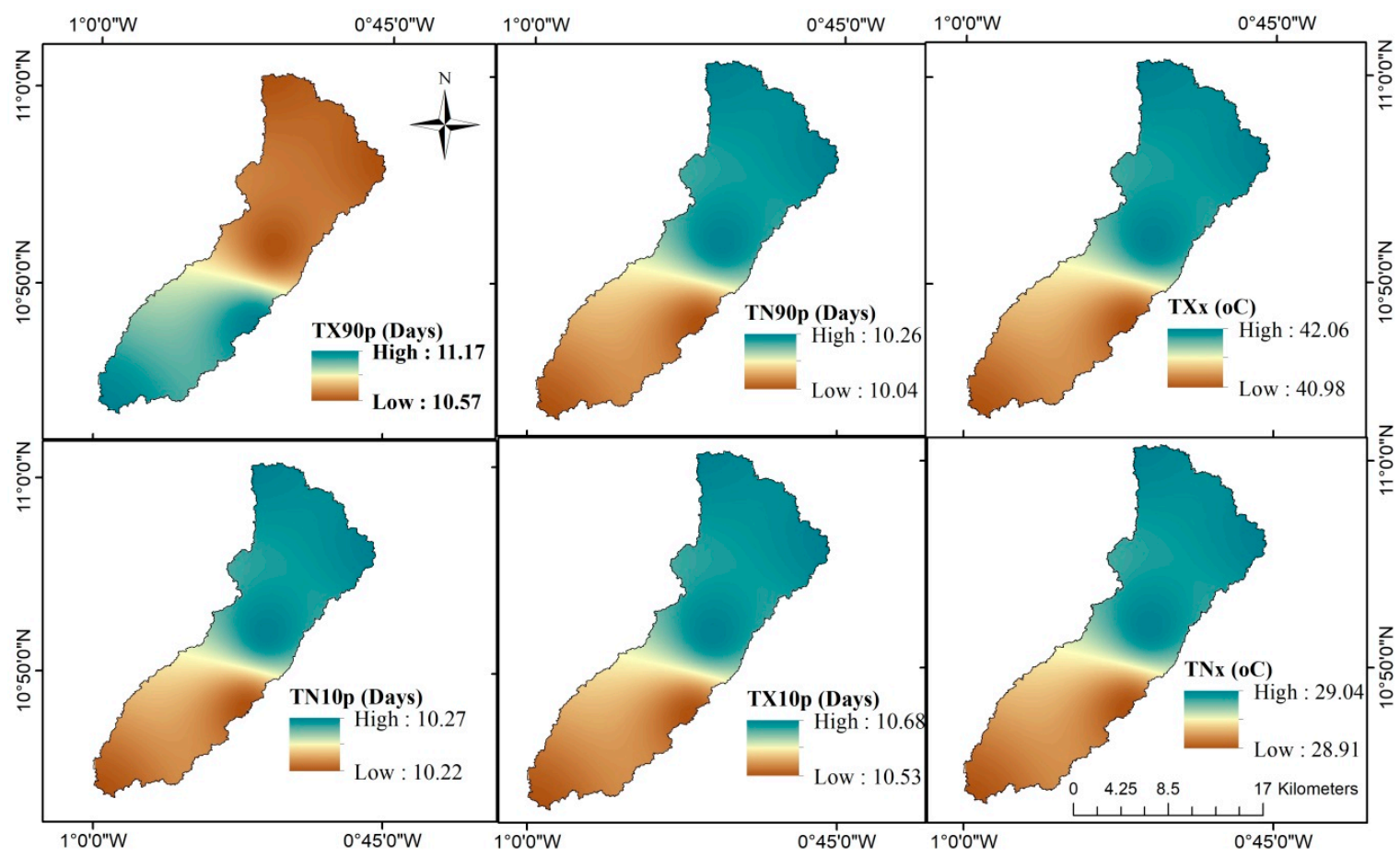

Figure 6. Spatial distribution of Temperature extreme Indices from 1985-2016.

\section{Discussion}

The scarcity of long-term spatially distributed quality climate data suitable for analysis of extremes is generally the greatest challenge in the quantification of extreme indices in West Africa. This study has demonstrated the capability of CHIRPS precipitation data in reproducing the current climate of the Vea catchment when compared with the station (Vea and Bolgatanga) data over the period 1990-2016 due to the limited and gap-free station data. In general, the CHIRPS data indicated high performance in terms of correlation coefficient, Nash-Sutcliffe efficiency, and percentage biases, hence its suitability for climate analysis over a similar region in West Africa. The good performance of the 
CHIRPS product may be due to its smaller grid size $(5 \mathrm{~km})$ as it reduces the effect of pixel-to-point comparison [36]. The ability of CHIRPS data in reproducing the climatology of the study region has also been demonstrated by other studies. For example, a study by [37] evaluation and comparison of satellite-based rainfall products in the sub-region showed that CHIRPS data perform well in the study region and hence can be used for further studies.

The rainfall extreme analysis based on Standardized Anomaly Index (SAI) for the Vea catchment over the period 1985-2016 indicated 1999 and 2003 as extremely wet years while 1989, 1991, 1994, 1999 and 2010 were all wetter than normal. These findings are in line with [23] study at the Vea catchment which indicated that the years 1999 and 2007 recorded the highest annual rainfall that led to flood at the study area. Records also show that 1989, 1995, 1999, 2007 and 2010 were years of widespread flooding in the region [38-40] that caused a lot of destruction to food crops and settlement. A study by [41] showed that high frequency of drought events over the period 1988-2012 had the devastating effects on agriculture production and contributed towards changing crop patterns at the study region. Their study observed that due to the higher frequency of drought events, more than $57 \%$ of farmers in the region have shifted from growing traditional crops such as sorghum, millet, groundnuts, and local potatoes, to improved and short-duration varieties of maize.

The analysis of extreme rainfall Indices based on the Expert Team on Climate Change Detection Monitoring Indices (ETCCDMI) at the Vea catchment show a general decrease in the intensity and magnitude of extreme precipitation indices but an increase in the frequency of extreme rainfall indices. The observed trend in the rainfall indices in terms of frequency and intensity at the Vea catchment have also been observed in previous studies and in other regions worldwide including the West Africa region. For example, a study by the authors of [28] found a general tendency of decreased annual total rainfall and the maximum number of consecutive wet days in most locations in West Africa. In a similar study by [30] over the Ouémé basin reported a significant declining in heavy and extremely heavy precipitation and annual total wet-day precipitation in most stations for the period 1950 to 2014 . A study by [42] assessed the changes of climate extremes within the Greater Horn of Africa (GHA). The results of their study showed a significant decrease in total precipitation in wet days greater than $1 \mathrm{~mm}$ and increasing warm extremes, particularly at night, while cold extremes are decreasing. The observed trend in the frequency Indices such as decreased in the maximum number of consecutive wet days and increase in consecutive dry days agrees with the results obtained by [30] in a similar climate region.

The temperature indices analyzed indicates that the frequency of warm nights and warm days has increased over the study period at the Vea catchment which conforms to the study of [41] that observed an increased in the number of warm days and warm nights in West Africa over the period 1961 to 2000. The evidence from the analysis indicates that the observed warming over the past years can be attributed to the increase in daily minimum temperature rather than daily maximum temperature. The observed increase in the daily maximum temperature (TXx) over the period conforms to the temperature trend analysis at the Vea catchment from 1972 to 2012 by Limantol et al. [28] that indicated warming of the area. The observed warming during the day (TX90p) and nights (Tn90p) is in line with the observed changes at the global scale which indicates the very likelihood of an increase in warm days and night [9]. A similar result was obtained from a study in West African Sahel by [28] which observed a general warming trend throughout the region during the period from 1960 to 2010, mainly through a negative trend in the number of cool nights, and more frequent warm days and warm spells. The increasing warm extremes at the Vea catchment can be attributed to the upward trends in minimum rather than maximum temperatures. A study conducted by [31] at the study area showed that the frequency and severity of diseases and sicknesses such as cerebrospinal meningitis, heat rashes, headaches and malaria-related to both dry and wet conditions have increased steadily over time. If the increasing trend persists, the excessive heat experienced at night may have severe implications for the health of the population in the area. 


\section{Conclusions and Recommendation}

This study analyzed climate extremes using the Standardized Anomaly Index and Indices from Expert Team on Climate Change Detection Monitoring Indices (ETCCDMI) for the Vea catchment from 1985 to 2016 using stations and gridded data. The performance of the gridded CHIRPS precipitation data was evaluated. The study revealed that the CHIRPS data was able to mimic both the seasonal and annual rainfall pattern of the study area reasonably well indicating its capability for further usage in other analysis at the study location. The catchment was noticed to have experienced variability in drier and wetter years over the study period. The trend in rainfall and temperature extremes indices obtained in this study indicates that the climate of the Vea catchment is moving towards a drier and warmer climate. The climate extreme study outcome indicates a decrease in the intensity of extreme precipitation indices over the catchment during the study period of 1985 to 2016. Most of the frequency of extreme rainfall indices was rather observed to be on an increase especially in the southern part of the catchment. The study also revealed that almost all temperature indices point to a general warming trend in the day and night during the study period. The observed warming trend means a higher evaporation rate from water bodies and irrigated crops while the higher frequency in extreme rainfall indices indicate the tendency of flood events. The outcome of this study gives an insight into the issue of drought/flood intensities and frequencies over the past years in the study area. This serve as a guide in developing policies to mitigate the effects of flood and drought such as; the use of rainwater harvesting systems as potential for flood and drought mitigation in the phase of climate change, the design of infrastructure and production systems to account for higher risks of losses due to floods or droughts, the development of early warning systems and the effective management of various agricultural and water resources projects at the Vea catchment.

Author Contributions: I.L., F.C.C.H., T.A., W.A.A., J.M.G. and J.A. designed the study, developed the methodology and wrote the manuscript. I.L. collected the data and performed the analysis; F.C.C.H., T.A., W.A.A., J.M.G. supervised the data analysis; J.A. contributed to paper write up.

Funding: This research received no external funding.

Acknowledgments: This paper was extracted from a Doctoral research study undertaken at Universite D'Abomey Calavi, Benin. My sincere appreciation goes to the Federal Ministry of Education and Research (BMBF) and West African Science Centre on Climate Change and Adapted Land Use (WASCAL; www.wascal.org) for providing the scholarship and financial support for this programme.

Conflicts of Interest: The authors declare no conflict of interest.

\section{References}

1. New, M.; Hewitson, B.; Stephenson, D.B.; Tsiga, A.; Kruger, A.; Manhique, A.; Gomez, B.; Coelho, C.A.S.; Masisi, D.N.; Kululanga, E.; et al. Evidence of trends in daily climate extremes over southern and west Africa. J. Geophys. Res. 2006, 111, D14102. [CrossRef]

2. IPCC Mitigation of Climate Change. The Contribution of Working Group III to the Fifth Assessment Report of the Intergovernmental Panel on Climate Change; Cambridge University Press: Cambridge, UK; New York, NY, USA, 2014.

3. Amuzu, J.; Jallow, B.P.; Kabo-Bah, A.T.; Yaffa, S. The Climate Change Vulnerability and Risk Management Matrix for the Coastal Zone of the Gambia. Hydrology 2018, 5, 14. [CrossRef]

4. Hegerl, G.C.; Zwiers, F.W.; Braconnot, P.; Gillett, N.P.; Luo, Y.; Orsini, J.A.M.; Nicholls, N.; Penner, J.E.; Stott, P.A. Understanding and Attributing Climate Change. In Climate Change 2007: The Physical Science Basis. Contribution of Working Group I to the Fourth Assessment Report of the Intergovernmental Panel on Climate Change; Solomon, S., Qin, D., Manning, M., Chen, Z., Marquis, M., Averyt, K.B., Tignor, M., Miller, H.L., Eds.; Cambridge University Press: Cambridge, UK; New York, NY, USA, 2007; pp. 663-746.

5. Pall, P.; Aina, T.; Stone, D.A.; Stott, P.A.; Nozawa, T.; Hilberts, A.G.; Lohmann, D.; Allen, M.R. Anthropogenic greenhouse gas contribution to flood risk in England and Wales in autumn 2000. Nature 2011, 470, 382-385. [CrossRef] [PubMed] 
6. Intergovernmental Panel on Climate Change (IPCC). Managing the Risks of Extreme Events and Disasters to Advance Climate Change Adaptation; A Special Report of Working Groups I and II of the Intergovernmental Panel on Climate Change; Cambridge University Press: New York, NY, USA, 2012; Available online: http:/ / www.preventionweb.net/files/24327_srexallfinal.pdf (accessed on 20 May 2017).

7. Jones, P.D.; Trenberth, K.E.; Ambenje, P.; Bojariu, R.; Easterling, D.; Klein, T.; Parker, D.; Renwick, J.; Rusticucci, M.; Soden, B. Observations: Surface and atmospheric climate change. Clim. Chang. 2007, 235-336.

8. Min, S.-K.; Zhang, X.; Zwiers, F.W.; Hegerl, G.C. Human contribution to more-intense precipitation extremes. Nature 2011, 470, 378-381. [CrossRef] [PubMed]

9. Solomon, S.; Qin, D.; Manning, M.; Averyt, K.; Marquis, M. Climate Change 2007-The Physical Science Basis: Working Group I Contribution to the Fourth Assessment Report of the IPCC; Cambridge University Press: New York, NY, USA, 2007; Volume 4.

10. Alexander, L.V.; Zhang, X.; Peterson, T.C.; Caesar, J.; Gleason, B.; Klein Tank, A.M.G.; Haylock, M.; Collins, D.; Trewin, B.; Rahimzadeh, F.; et al. Global observed changes in daily climate extremes of temperature and precipitation. J. Geophys. Res. Atmos. 2006, 111. [CrossRef]

11. Moberg, A.; Jones, P.D. Trends in indices for extremes in daily temperature and precipitation in central and western Europe, 1901-99. Int. J. Climatol. 2005, 25, 1149-1171. [CrossRef]

12. Sarr, B. Present and future climate change in the semi-arid region of West Africa: A crucial input for practical adaptation in agriculture. Atmos. Sci. Lett. 2012, 13, 108-112. [CrossRef]

13. FAO; IFAD; WFP. The State of Food Insecurity in the World 2013. The Multiple Dimensions of Food Security; FAO: Rome, Italy, 2013; ISBN 978-92-5-107916-4.

14. Amuzu, J.; Kabo-Bah, A.T.; Jallow, B.P.; Yaffa, S. Households' Livelihood Vulnerability to Climate Change and Climate Variability: A Case Study of the Coastal Zone, the Gambia. J. Environ. Earth Sci. 2018, 8, 35-46. [CrossRef]

15. Bohle, H.G.; Downing, T.E.; Watts, M.J. Climate change and social vulnerability: Toward a sociology and geography of food insecurity. Glob. Environ. Chang. 1994, 4, 37-48. [CrossRef]

16. Arnell, N.W. Climate change and global water resources: SRES emissions and socio-economic scenarios. Glob. Environ. Chang. 2004, 14, 31-52. [CrossRef]

17. Jones, P.D.; Horton, E.B.; Folland, C.K.; Hulme, M.; Parker, D.E.; Basnett, T.A. The use of indices to identify changes in climatic extremes. Clim. Chang. 1999, 42, 131-149. [CrossRef]

18. Data, C. Guidelines on Analysis of Extremes in a Changing Climate in Support of Informed Decisions for Adaptation; World Meteorological Organization: Geneva, Switzerland, 2009.

19. Yazid, M.; Ismail, N.A.; Yazid, M.; Yunos, M.; Ismail, S. Malaysia Going Greens: A Study on Community Commitment towards a Greener Urban Living Environment. Adv. Environ. Biol. 2015, 9, 498-503.

20. Donat, M.G.; Alexander, L.V.; Yang, H.; Durre, I.; Vose, R.; Dunn, R.J.H.; Willett, K.M.; Aguilar, E.; Brunet, M.; Caesar, J. Updated analyses of temperature and precipitation extreme indices since the beginning of the twentieth century: The HadEX2 dataset. J. Geophys. Res. Atmos. 2013, 118, 2098-2118. [CrossRef]

21. Kunkel, K.E.; Easterling, D.R.; Redmond, K.; Hubbard, K. Temporal variations of extreme precipitation events in the United States: 1895-2000. Geophys. Res. Lett. 2003, 30. [CrossRef]

22. Haylock, M.R.; Peterson, T.C.; Alves, L.M.; Ambrizzi, T.; Anunciação, Y.M.T.; Baez, J.; Barros, V.R.; Berlato, M.A.; Bidegain, M.; Coronel, G. Trends in total and extreme South American rainfall in 1960-2000 and links with sea surface temperature. J. Clim. 2006, 19, 1490-1512. [CrossRef]

23. Peterson, T.C.; Manton, M.J. Monitoring changes in climate extremes: A tale of international collaboration. Bull. Am. Meteorol. Soc. 2008, 89, 1266-1271. [CrossRef]

24. Limantol, A.M.; Keith, B.E.; Azabre, B.A.; Lennartz, B. Farmers' perception and adaptation practice to climate variability and change: A case study of the Vea catchment in Ghana. SpringerPlus 2016, 5, 830. [CrossRef] [PubMed]

25. Funk, C.; Peterson, P.; Landsfeld, M.; Pedreros, D.; Verdin, J.; Shukla, S.; Husak, G.; Rowland, J.; Harrison, L.; Hoell, A. The climate hazards infrared precipitation with stations-A new environmental record for monitoring extremes. Sci. Data 2015, 2, 150066. [CrossRef] [PubMed]

26. World Meteorological Organization (WMO); Global Water Partnership (GWP). Handbook of Drought Indicators and Indices; Svoboda, M., Fuchs, B.A., Eds.; Integrated Drought Management Programme (IDMP) Tools and Guidelines Series 2; Integrated Drought Management Programme: Geneva, Switzerland, 2016. 
27. Hayes, M.J.; Svoboda, M.D.; Wilhite, D.A.; Vanyarkho, O.V. Monitoring the 1996 drought using the standardized precipitation index. Bull. Am. Meteorol. Soc. 1999, 80, 429-438. [CrossRef]

28. Peterson, T.C.; Taylor, M.A.; Demeritte, R.; Duncombe, D.L.; Burton, S.; Thompson, F.; Porter, A.; Mercedes, M.; Villegas, E.; Semexant Fils, R.; et al. Recent changes in climate extremes in the Caribbean region. J. Geophys. Res. Atmos. 2002, 107. [CrossRef]

29. Mouhamed, L.; Traore, S.B.; Alhassane, A.; Sarr, B. Evolution of some observed climate extremes in the West African Sahel. Weather Clim. Extrem. 2013, 1, 19-25. [CrossRef]

30. Soro, G.E.; Noufé, D.; Goula Bi, T.A.; Shorohou, B. Trend analysis for extreme rainfall at sub-daily and daily timescales in Côte d'Ivoire. Climate 2016, 4, 37. [CrossRef]

31. M'Po, Y.N.; Lawin, E.A.; Yao, B.K.; Oyerinde, G.T.; Attogouinon, A.; Afouda, A.A. Decreasing Past and Mid-Century Rainfall Indices over the Ouémé River Basin, Benin (West Africa). Climate 2017, 5, 74. [CrossRef]

32. Yiran, G.A.B.; Stringer, L.C. Spatio-temporal analyses of impacts of multiple climatic hazards in a savannah ecosystem of Ghana. Clim. Risk Manag. 2016, 14, 11-26. [CrossRef]

33. Okafor, G.C.; Jimoh, O.D.; Larbi, K.I. Detecting Changes in Hydro-Climatic Variables during the Last Four Decades (1975-2014) on Downstream Kaduna River Catchment, Nigeria. Atmos. Clim. Sci. 2017, 7, 161-175. [CrossRef]

34. Önöz, B.; Bayazit, M. The power of statistical tests for trend detection. Turk. J. Eng. Environ. Sci. 2003, 27, 247-251.

35. Sen, P.K. Estimates of the regression coefficient based on Kendall's tau. J. Am. Stat. Assoc. 1968, 63, 1379-1389. [CrossRef]

36. Omondi, P.A.; Awange, J.L.; Forootan, E.; Ogallo, L.A.; Barakiza, R.; Girmaw, G.B.; Fesseha, I.; Kululetera, V.; Kilembe, C.; Mbati, M.M.; et al. Changes in temperature and precipitation extremes over the Greater Horn of Africa region from 1961 to 2010. Int. J. Climatol. 2013, 34, 1262-1277. [CrossRef]

37. Cohen, L.T.; Matos, J.; Boillat, J.L.; Schleiss, A. Comparison and Evaluation of Satellite Derived Precipitation Products for Hydrological Modeling of the Zambezi River Basin. Hydrol. Earth Syst. Sci. 2012, 16, 489-500. [CrossRef]

38. Moctar, D.; Zwart, S.J. Evaluation and comparison of satellite-based rainfall products in Burkina Faso, West Africa. Int. J. Remote Sens. 2016, 17, 3995-4014. [CrossRef]

39. The World Bank Group. Disaster Risk Management Programmes for Priority Countries. Global Facility for Disaster Reduction and Recovery (GFDRR); The World Bank: Washington, DC, USA; International Strategy for Disaster Reduction (ISDR): Geneva, Switzerland, 2009.

40. UNDP (United Nations Development Programme). Recovery Support for Northern Ghana; UNDP: Accra, Ghana, 2009.

41. NADMO (National Disaster Management Organization). A PowerPoint Presentation by NADMO. Bolgatanga. Available online: http://mofafoodsecurity.files.wordpress.com/2011/06/presentation-bynadmo-20111.ppt (accessed on 3 September 2018).

42. Hirsch, R.M.; Slack, J.R.; Smith, R.A. Techniques of trend analysis for monthly water quality data. Water Resour. Res. 1982, 18, 107-121. [CrossRef]

(C) 2018 by the authors. Licensee MDPI, Basel, Switzerland. This article is an open access article distributed under the terms and conditions of the Creative Commons Attribution (CC BY) license (http://creativecommons.org/licenses/by/4.0/). 